\title{
Three Men Teachers, Three Countries And Three Responses to the Physical Contact Dilemma
}

\author{
Penni Cushman \\ College of Education, University of Canterbury \\ Private Bag 4800, Christchurch 8140, New Zealand \\ Tel: 0064-3-3458-131Ｅ-mail: penni.cushman@canterbury.ac.nz
}

\begin{abstract}
The shortage of men teachers in primary schools is a global concern. As the demand for men teachers expands, the reasons why men choose not to teach, also grows. In some countries a media-fuelled fear of being accused of sexual abuse, and resultant policies designed to protect students and teachers, has deterred potential applicants and impacted on the freedom of men teachers to engage with students in gender-neutral, nurturing ways. At the same time as men are feeling compelled to act in keeping with traditional masculinities, gender equity policies are directing schools to challenge damaging stereotypes and encourage diversity in life choices. This paper investigates how three men in three countries - England, Sweden and New Zealand - have responded to these conflicting messages and how they have modified their physical contact in light of perceived risks. Although the size of the study restricts the validity of the findings, the paper highlights the complexity of factors that influence men teachers, including cultural mores, and adds to the call for more intensive teacher education around gender.
\end{abstract}

Keywords: Men teachers, Physical contact, Gender issues 


\section{Introduction}

Media attention paid to issues concerning adult physical contact with children has not only adversely affected the numbers and attitudes of potential primary school teaching applicants, but also influenced the practices of men teachers in the classroom. In a number of countries, men's apprehension of being accused of child abuse and paedophilia, fuelled by media hype, has deterred men from taking up teaching or staying in the profession once there, and has created confusion for men teachers over what physical approach to take with children (Carrington, 2002; Cushman, 2005a). In New Zealand, a climate of fear resulting from one highly publicised case of suspected abuse by a male pre-school worker (for an account, see Hood, 2001) was exacerbated in 1998 by the development of the teacher union's policy advocating no physical contact between teacher and student (New Zealand Education Institute, 1998). Designed with the intention of protecting all teachers, the policy only added to the prevailing confusion, stress and suspicion, and further emphasised gender inequities in teachers' practices (Cushman, 2005b). In other countries, similar governmental and school policies have been developed to provide guidelines for teachers' physical interactions with children (Skelton, 2001). Men who have responded to such policies by resorting to "hands-off" relationships are compelled to conform to a traditional or hegemonised form of masculinity in which a physical and emotional distance from relationships is maintained (Skelton, 2000). While the New Zealand policy was amended in 2006 to suggest physical contact in some situations was acceptable, and even desirable, the damage had already been done, and men, in particular, were reluctant to change practices of self-protection (Cushman, 2005b).

The extent to which teachers in other countries consider themselves to be at risk of allegations of sexual abuse of students, and whether this consideration affects their practices and the extent to which they want to stay teaching, has relevance in light of pressure in many countries to increase the numbers of men teachers (Cushman, 2005b). It seems fair to assume that physical contact with students in any one country reflects cultural attitudes and mores around the accepted physicality of men and women's interpersonal relationships. Furthermore, in those countries where guidelines are in place regarding teachers' physical contact with students, one would expect these to influence teacher (whether male or female) interactions with students.

At the same time as teachers in various countries were being cautioned to avoid physical contact with students, many of these countries were also instigating policies and guidelines designed to redress gender discrimination by promoting democratic values, gender equality, and social justice (Foster \& Newman, 2005; Human Rights Commission, 1993; Taguchi, 2005). The incongruity of men teachers feeling compelled to perform a hegemonised version of masculinity in an environment committed to encouraging equality between the genders is evident. How men " "manage”" this disparity has largely been overlooked in the literature.

In 2008, I was fortunate to spend time in schools and universities in England, Sweden, and New Zealand, speaking to men about the gender-related issues they faced in their profession as primary school teachers. One aspect I was particularly interested in was how men 
negotiated their way through the aforementioned seemingly contradictory expectations. As Foster and Newman (2005) observe, teachers need to engage in relationships with students that sit comfortably with their individual personalities as well as their perceived roles as an effective teacher. For some men, this relationship might be influenced by the compatibility between their natural predisposition toward exhibiting certain behaviours and their fear of such behaviours being misconstrued as potentially abusive. In considering this matter, Martino (2008) calls for teachers to reflect on their teaching practices and assumptions, and to engage in their preferred behaviours, thereby reflecting the fluidity and diversity of gender.

The aim of this paper is to contribute to the literature that provides insights into men teachers and their gender-related classroom practices. The paper focuses on three men in three countries and the extent to which they had modified their physical contact with students in light of perceived issues or risks. How these three men had attempted to negotiate their students' needs for physical contact while protecting themselves from potential allegations of abuse is tentatively investigated. I cannot claim therefore that the study is rigorous in terms of its research methodology; nor can I - and readers - assume that the behaviours and attitudes of the three men teachers reflect those of all men teachers in England, Sweden and New Zealand. Nonetheless, I hope that their experiences and reflections will add some useful insights and provide direction for further research. Also, given that teachers are an important agent of change, I consider and discuss in this paper how well these teachers' behaviours and attitudes align with the principles inherent within the current trend to promote gender equity and social justice.

\section{Background}

Over the second half of the 20th century and the first years of this new century, the number of men teachers in primary schools declined in England, Sweden and New Zealand to the point where teachers in each county now comprise less than $20 \%$ of the primary school teacher workforce (UNESCO Institute for Statistics, 2008). Each country has responded to the decline with measures aimed at recruiting men teachers in greater numbers (Arreman \& Weiner, 2007; Carrington, 2002; Cushman, 2007). The major reasons underpinning the need for more men teachers in Sweden relate to policies and practices promoting gender equity and a desire to have both sexes equally represented in various spheres of society (Berge, 2004). While these reasons feature in discourse calling for more men teachers in England and New Zealand, greater prominence seems to be given in these two countries to concerns about boys' scholastic underachievement and behaviour, and to the (aligned) need for male role models (Carrington, 2002; Cushman, 2007).

Concerns around issues of potential sexual abuse of students by teachers, particularly men, and media attention to incidences of alleged abuse in the school environment have plagued all three countries to varying extents (Berge, 2004; Cushman, 2005b; Skelton, 2001). As a result, each country has implemented measures to address the potential for allegations of sexual abuse by teachers. In Sweden, an important aspect of the measures put in place was that, in the interests of gender equality, they did not frighten men away (Berge, 2004). Berge claimed that the ensuing legal processes in Sweden transferring the governing of schools to locally 
based educational stakeholders (teachers and parents) were in part designed to increase parents' confidence in men teachers and to lessen their suspicion of them as potential "predators". In England and New Zealand, moves to safeguard teachers have tended to focus on restricting physical contact between teachers and students. Although directed at all teachers, these measures tend to have been interpreted in school environments as an issue of concern mainly for men (Cushman, 2005b; Thornton \& Bricheno, 2006). Sweden, despite intermittent media attention to incidents of abuse of students, has no formal policies around physical contact with students.

In 1998, the same year as teachers in New Zealand were being told they must adhere to a strictly "hands off" code of practice, teachers in Sweden were being advised that the way boys and girls are addressed and valued in school, and the demands and expectations that are placed on them, are important factors in student understanding of what is female and male. As Taguchi (2005) pointed out, the school's responsibility for counteracting traditional gender patterns was being made abundantly clear. These attitudes were encapsulated in Sweden's school law of 2005, which stated that school practice must be based on democratic values, with all teachers and staff advocating gender equality (Jacobsen, Kjeldsen, \& Poulson, 2006; Taguchi, 2005). In 2004, Sweden was ranked highest of all countries in Europe for equality between the sexes (Berge, 2004), so it is possible that recommendations potentially seen as targeting one sex would have been considered untenable, and thus we might expect physical contact with children to be less of a gender issue in Swedish schools.

In contrast, in New Zealand, where the "hands-off" directive was expected to be adhered to by all teachers, many teachers understood it to be directed mainly to men, and it was therefore men, and rarely women, who modified or rationalised their practices accordingly (Cushman, 2005b). Cushman found some men teachers had no need to adhere to the guidelines restricting behaviours associated with nurturing, caring and physical contact with students given their practice already exemplified this approach. For others, adherence entailed engaging in traditionally stereotypic behaviours that did not necessarily sit comfortably with their natural predisposition. In New Zealand, a country where losing the rugby world cup is viewed as a global disaster (Ferguson, 2004), and dominant masculinities are strongly associated with this sport, the guidelines may have helped consolidate a belief that the desired attributes of men teachers and rugby players have much in common. As Ferguson (2004, p. 82) explains, "Rugby is rough, confrontational, a real test of physical superiority, and in New Zealand it is fiercely competitive. Because of its status as the national game, these values are exalted and seen as natural masculine qualities.”

Epstein, Elwood, Hey, and Maw's (1998) observation that football signifies masculinity indicates that the tenor of Ferguson's quote is not limited to New Zealand. In 1996, Salisbury and Jackson (1996) noted that desirable aspects of hegemonic masculinity in England included the aggressive performance, physical strength and emotional stoicism associated with the sport. Four years on, Skelton (2000) found that football took a central place in the classroom management strategies of some men teachers in England. In addition to the aspects highlighted by Salisbury and Jackson, Skelton noted men teachers exhibiting the "laddish" personality characteristics associated with football when engaging with male students in 
particular, such as "having a laugh" and focusing on pastimes and subjects constructed as masculine.

With pressure on schools to appoint men teachers as role models, particularly for boys, as has been the case in New Zealand, it is not surprising that men who fit with the masculine ideal are in demand. A study of New Zealand principals (Cushman, 2007) found that both male and female principals favoured male teacher applicants who demonstrated the characteristics of hegemonic masculinity. This expectation was also evident in beginning men teachers in England, who reported fears of being perceived as "deviant" if they behaved in non-stereotypically masculine ways (Francis \& Skelton, 2001; Martino \& Berrill, 2003). Such anxieties are commonly grounded in the public perception of the association of non-normative masculinities with attributions of homosexuality, which in turn are conflated with paedophilia (Martino \& Berrill, 2003). Francis and Skelton's (2001) finding that men risk marginalisation from peers if they do not "achieve" an acceptable construction of masculinity further justifies Roulston and Mills’s (2000) claim that homophobia often works in "insidious ways to reinforce dominant constructs of masculinity" (p. 227).

Teaching older children in the primary school may be more readily reconciled with dominant notions of masculinity given that teaching younger students tends to be more closely associated with caring and nurturing, traditionally feminine traits (Carrington, 2002). Jones (2003) found young children actively seek physical contact with their teachers, a need on the part of the children that leads to a deep contradiction between what their teachers know is important and vital for them to be doing in their work, and their own needs for selfprotection. This type of conflict leads to "identity bruising", to use a phrase coined by Foster and Newman (2005). Men in Foster and Newman's study managed their “bruising” by using pedagogical rather than physical approaches, such as circle time and social education, to express empathy with the children. The irony is that evidence shows many allegations of abuse have little to do with students misconstruing touch and that withdrawal of physical contact will not protect the teacher (Farquhar, 2001). Notwithstanding this, Jones (2003) found injunctions against "unguarded touch" had become normalised in teacher education programmes.

At the same time as there appears to be strong societal forces operating to encourage or maintain men's adherence to traditionally masculine behaviours and practice, there is an increasingly substantive body of work supporting the theory that "high status constructions of masculinity” (Skelton, Francis, \& Valkanova, 2007, p. 19) are likely to have a negative impact on the achievement of boys (Francis \& Skelton, 2005; Younger, 2007). Concern centred on the "problems with boys" has dominated educational agendas for the last decade, and current findings linking the "problems" with hegemonic masculinities would suggest a need for concomitant changes in schools. Recently, however, Martino (2008) employed an analytical framework to illustrate the extent to which the role model discourse is "part of a broader cultural project of re-masculinization” (p.217). He concluded that schools tend to promote both explicitly and implicitly a narrow version of masculinity and make little attempt to encourage boys to develop a broader definition of what it means to be male. Recognising the value of expressivity, emotional literacy and nurturing capacities, Martino 
(2008) favours a constructivist approach that focuses on providing boys with role models that allow them to visualise other ways of being male. The importance of this is clear when reflecting on Renold's (2004) finding that more than two-thirds of boys in her study expressed discontent over the pressures to perform a hegemonic masculinity. Notwithstanding such observations, Martino (2008) noted he had seen very few men teachers committed to working with boys to encourage them to be nurturing, caring and "in touch with their feelings". Martino added that a failure to promote such critical thinking in schools "is to abnegate our social and ethical responsibilities as educators” (p. 3).

The adoption by men teachers of more gender-neutral behaviours appears to be associated with a fear of how they will be viewed, to the extent that homophobia is preventing the development of a healthy masculinity (Ferguson, 2004; Francis \& Skelton, 2001; Lingard \& Douglas, 1999). It is concerns such as this that add import to Martino, Lingard, and Mills's (2004) claim that schools must not only acknowledge the social construction of gender but also challenge dominant constructions of masculinity (and femininity). Martino and Berrill (2003) found men to be less willing than women to interrogate the social construction of masculinities, particularly the hegemonic heteronormativity that these researchers contend is entrenched in the school environment.

\section{Method}

The data discussed in this paper are drawn from a small preliminary investigative study of men teachers in three countries - England, Sweden and New Zealand. England and Sweden were selected in order that cross-national comparisons could be made with data collected in New Zealand. In New Zealand, I personally contacted the principals of four schools requesting that they ask men teachers on their staff if they would be prepared to participate in the study. I used university and teacher colleagues to provide me with potential men teacher contacts in England and Sweden. Twelve men in total were interviewed, three in England, five in Sweden and four in New Zealand. My talks with these men involved semi-structured interviews that varied in length from 50 minutes to one hour and 15 minutes. For the purposes of this paper, I present and discuss data from three interviewees, one from each country. These three provided comprehensive and useful insights into the impact of hegemonic masculinities and cultural mores on their relationships with students, particularly in terms of physical contact. In addition, the information they provided best exemplified the commentary and issues raised by the other nine interviewees.

The issue presented by a female researcher interviewing male teachers needs to be acknowledged. I was a woman talking to men about gender-related issues that challenged the core of their identity, and it is therefore possible that a power differential may have existed between the men and I during the course of the interviews. Furthermore, cultural differences between the three countries might have influenced aspects of all the interviews I conducted, such as the level of disclosure the interviewees were prepared to engage in and issues around language. For the Swedish participants, English was their second language, and it is possible that the framing of my questions may have lead to particular patterns of responses.

The interview questions included, but were not always limited to, the following: 


\section{MInstitute ${ }^{\text {Macrothink }}$}

International Journal of Education

ISSN 1948-5476

2009, Vol. 1, No. 1: E7

1. Can you recall any education around physical contact between teachers and students in your training to be a teacher?

2. Have you had any formal or informal education around your relationships with students since you have been teaching?

3. Tell me about your own beliefs and practices in terms of physical contact with your students?

4. Do you think your beliefs and practices are similar to those of other teachers in your school?

The interviews were audio-recorded and the confidentiality of interview responses guaranteed. The responses were fully transcribed by a research assistant in New Zealand. Substantive statements in each interview transcript were initially highlighted on the transcript and later, double-checked. From these a set of categories was determined for each interview question and the substantive statements were placed within the appropriate categories on an analysis grid. This organisation of substantive statements was important in determining the potential significance of the participants' responses. Cross-coding from the analysis grid to the specific transcripts ensured a simple process of referring back to the transcripts when the context of the statement required further investigation. I utilised a social constructionist and poststructuralist discourse analytic perspective (Burman \& Parker, 1992) to make sense of the qualitative data. Verbatim comments from participants are included in the presentation of findings below for illustrative purposes. The names of the interviewees are pseudonyms.

\section{1 The Three Cases}

- Ronnie (England) was a 25-year-old teacher in his second year of teaching at a north London school. He was teaching a Year 1 class (five- to six-year-olds) and was one of three men teachers in his school.

- Ivan (Sweden) was a 32-year-old teacher in his fifth year of teaching in an urban school in Malmo. He was teaching a Year 4 class (9 to 11-year- olds) and was one of five men teachers in his school.

- Tim (New Zealand) was a 35-year-old teacher, with six years of teaching experience in Christchurch. He was teaching a Year 6 class (9- to 11-year-olds) and was one of three men teachers in his school.

\section{Results and Discussion}

\subsection{Ronnie (England)}

Ronnie could recall discussing child-protection issues during his university training and more recently in an in-service course at his school. Consequently, while he found it unavoidable and also considered it important to engage in physical contact with his Year 1 class, he was very aware of the potential risk.

I've been on a course and it's very restrictive. You have to hold them like this and you have to 
hook them from the side, and all this type of stuff. You shouldn't be doing it, otherwise allegations might be brought against you and, yeah, it's shocking, especially when some kids do need that. We know as a school we have to implement it, but we also know it's impractical because there were jokes being made and all that type of stuff. Imagine a kid running up to a teacher and sort of, like, hug them, and we'll be looking at them sideways to make sure you hug them at the side. I hate to use the word silliness, but you know that's it.

For Ronnie, there was clearly conflict in what he sensed the children needed and what he was being directed to deliver. Ronnie's comments demonstrate the "deep contradiction" experienced by some men teachers (Jones, 2003). He was aware of the importance of touching and at the same time aware of the importance of not touching. The fact that what he had learned in teacher education had recently been reinforced in an in-service course highlighted, for him, the seriousness of the issue and the necessity to monitor his interactions with students. However, Ronnie saw the difficulties and impracticalities of implementing the "side hug" (where student and teacher stand side by side facing the same way and the teacher places his arm around the student's shoulder) as bordering on "silliness". Ronnie also suggested teachers could become "hug police”, monitoring and judging their colleagues' physical interactions with students.

Before attending the in-service course, Ronnie had responded to children's needs in a manner he felt comfortable with and that he felt met the children's needs. The traditionally feminine traits he employed (Carrington, 2002) had felt natural and appropriate. "Before [the course], they'd come up to me, and they're like limpets, and they clamber onto you, you know the type of thing, but whoa, not now." As a result of the course, Ronnie considered alternative practices he could engage in. Similar to the subject in Foster and Newman's (2005, p. 351) study, Ronnie was forced to "take positive and considered action to resolve his dilemma."

I've substituted it with more talking. Now it's a side hug, but then I've sort of put it with, "Oh, did you watch this programme last night?" So the child is distracted from the fact he's not getting a real hug, but you're still creating a relationship, and I think the child still gets the same similar response.

While Ronnie had followed the guidelines and changed his mode of interaction, his doing so entailed a concerted and continued effort to ensure boundaries were not being overstepped and that the child concerned remained unaware that the hug was not the same as one experienced in previous interactions with Ronnie. Forced to negotiate an identity far from his ideal, he appeared to have accepted the change as a professional necessity (Foster \& Newman, 2005). However, he was aware that female teachers had not altered their practices as a result of the course.

If they're acting professionally, then they shouldn't do it, and I know it sounds really sexist, but if you've got, like, a maternal sort of thing, then they put them on their lap, especially with the younger years. But, um, a child on the lap, if you're working to the book, irrespective of sex, you shouldn't. If a parent sees a female teacher with a child on their lap, or a male teacher - a parent might see that differently, which is sad, because we're just as trained as a female. 
Ronnie recognised that whether teachers' practices had changed as a result of the course depended on the teacher's gender. There appeared to be some conflict in Ronnie's thinking about the application of the rule for male and female teachers. His reference to the "maternal sort of thing" suggests his perception that having a child on one's lap was permissible (on the part of society) for a woman to the point of being almost natural. Ronnie's knowledge that he could not engage with children in a manner similar to his female colleagues set up a conflict for him. However, he saw the teacher designation as overriding the gender designation, thereby establishing the need for all teachers to adhere to the same policies. His concern about the attitudes of parents in terms of acceptable practices for male and female teachers can be seen as a reflection of societies that have yet to eliminate gender stereotypes (Thornton \& Bricheno, 2006).

While the education field might, in theory, advocate for equality, Ronnie was aware that gender discrimination still marginalises men who choose to teach young children and that there is a need for such men to protect themselves by not engaging in behaviours with students that might make them "suspect". Where Ronnie might previously have put an arm around a child who was off- task or daydreaming as a way of re-focussing their attention, he now resorted to safer practices.

I'll creep up on them and go "Boo", that type of thing, and they'll jump and go "Oh!" and then they'll carry on with their work ... Today there was this kid in my class - he just wanted it, he just needed it, you know-so I gave him a tickle, you know, that type of thing. And that's a fun thing, you know, and he was learning the difference, the boundaries.

The actions Ronnie said he had chosen to replace the more "feminine" and potentially suspect methods of physical contact could be seen as more typically masculine behaviours (Epstein et al., 1998; Skelton, 2001). Rather than hugging children or letting them climb on him, Ronnie now used humour couched in a more aggressive movement of creeping up and startling the child. But "tickling”, saying "Boo!” and giving a child a fright are dubious substitutes if that child needs affirmation or physical contact. That Ronnie had changed (in line with the course directive) his ways of relating with his students part-way through the school year cannot have gone unnoticed by the students. Their interpretation of the change, without any accompanying explanation, might have had implications for their view of the teacher's feelings towards them and their associated sense of self-worth. This is of particular concern given that Ronnie's earlier interactions were more gender-neutral, providing students with a role model that allowed them to visualise other ways of being male (Martino, 2008). Of even greater concern is that, if we accept Francis and Skelton's (2005) findings that more masculine traits are likely to impede academic achievement, Ronnie's changed behaviour could be seen as having multiple potential negative repercussions for his students.

\subsection{Ivan (Sweden)}

Unlike Ronnie, Ivan had no recollection of directives on physical contact with students from either his teacher education days or his time at his school. Because there had been no "warnings", he said that he did not regard physical contact as an issue of personal concern. He also said that he could not recall any discussions on the matter, and that the nature of his 
personality was such that he was not inclined to engage in physical contact readily in or out of school: "I'm not a huggy person, so I don't, I don't hug a lot otherwise either, so, um, I don't hug students very often, no. On the last day of semester, I do, but um, not otherwise." Ivan offered his claim that he was not a "huggy" person at school or otherwise, as a reason for why he engaged in less physical contact than the other teachers in his school. He said he knew other men teachers who hugged their students every day. However, if a child was distressed and approached Ivan, he conceded he would naturally hug the student. This was not the "token" sideways hug adopted by Ronnie in England, but a front hug.

In contrast with the other two interviewees, Ivan appeared more accepting of the fluidity and diversity of gender (Martino, 2008), perhaps because he remembered many discussions on gender equality during his pre-service teacher education and because he said he had experienced continued questioning and challenging of gender stereotypes since. From my interviews and informal discussions with male and female Swedish teachers, I gained the impression that teachers generally hugged each child as they left class at the end of the semester. Ivan's reference to this occasion and his comments overall strongly indicated that Ivan viewed physical contact with students as a natural component of student-teacher interactions, when desired, regardless of whether the teacher was male or female.

At one point in the interview, I asked Ivan if he thought male and female teachers related differently to their students. This was his reply:

We do things different because we are different individuals. But if that's because we are men and women, I don't know, but, ah, yes, of course, I do some things different than the women colleagues, but then again I do some things different from the men colleagues as well. I don't know if that's because I'm a man and she's a woman or if we're just different individuals, but some students learn better my way and some hers, so we complement each other.

Ivan's response reinforces his earlier suggestion that teachers' styles generally reflect personalities rather than gender differences, a response that sits comfortably with Taguchi's (2005) claim that all teachers and staff in Sweden are expected to advocate for gender equity. Ivan appeared unsure if differences in teaching style could be attributed to gender or personality, but because he saw the differences as complementary, he would probably have found it difficult to provide a reason as to why either teaching approach needed to be changed in any way.

Ivan's declared lack of "huggy" personality and his conjecture about male versus female ways of teaching appeared to be compromised in the playground where he saw himself targeted by students wanting to "wrestle" him: "When I am out on the break, some of the boys and girls in this class, they come and find me, and then they will push me and, ah, they will pull my jacket and try to take my cap or something like that. And I push them a bit and stuff like that." Moreover, although Ivan could remember no formal or informal warnings about the vulnerability of teachers to accusations of abuse, his comments regarding media attention to the issue (Berge, 2004) and his description of his practice regarding physical contact with older girls in the school had apparently influenced his thinking to some extent: 
Of course when the girls turn eleven, twelve, there are some parts of the body where you shouldn't ... I must avoid. If I hug a girl from behind, I must be careful where I put my arms, and when they play with me on the breaks-sometimes we can wrestle for fun or something like that-I'm a little more careful with the girls where I put my hands than with the boys.

Ivan's willingness to engage in - and apparent enjoyment of - physical contact with his students in the playground, along with his practice of constraining his physical contact with older girls suggests that his reasoning that physical contact with students not only suggests some confusion in Ivan's own mind over the appropriateness of physical contact with students. His claim that how teachers act physically with students is attributable to individual differences in personality was possibly simplistic on his part. Although Swedish schools have no formal policies restricting physical contact, and teachers and students therefore presumably feel able to continue engaging in nurturing and affirming physical contact at all levels of the school system, Ivan's willingness to engage in wrestling with students in the public arena of playground, despite his claim of not being a "huggy" person, could have result from an acknowledgement that physical contact is best conducted in a public arena and also from a subconscious need to affirm his masculinity through engaging in typically masculine behaviours (Epstein et al., 1998; Skelton, 2001). Ivan may have seen, whether consciously or unconsciously, his open display of physical contact with students in the playground as less risky behaviour than giving an emotional student a frontal hug in the comparative privacy of an office or classroom.

Ivan's comments regarding taking care with older girls are also interesting. First, and although Carrington (2002) suggests teaching older students generally involves less need for physical contact, it is apparent that the "not huggy" Ivan was still hugging his 9- to 11year-old female students, to the extent of approaching girls from behind, but nonetheless taking care where he placed his hands. On one level, Ivan seemed to accept that teachers can hug students, but on another, he was aware of the need to exercise caution, especially with young girls who presumably were entering or well into puberty, suggesting a conflated understanding that touch can have a sexual element.

\subsection{Tim, New Zealand}

It was clear from the beginning of my interview with Tim that the main influence on his stance regarding physical contact with his students was his recent reading about the needs of boys, notably Steve Biddulph's Raising Boys (1997), and not New Zealand's policy guidelines on the matter (New Zealand Education Institute, 1998). Tim's commentary revealed that his pedagogical beliefs aligned with recuperative masculinities discourses (Martino, Lingard, \& Mills, 2004). Recuperative masculinists argue that boys and male teachers are victims of feminisation (Martino, 2008), and that subsequently there is a need for teaching approaches and strategies that address and respond to the distinct needs of boys (Younger, 2007). The role of sport in reproducing and confirming masculinity (Epstein et al., 1998) is supported in Tim's case because sport, particularly football, permeated his pedagogical practices and relationships with his students. Tim said that he frequently used football as a disciplinary and motivational tool and as a means of creating relationships with 
the "guys". His style strongly resembled the "laddish culture" critically analysed by Skelton (2001). Tim's use of football to manage his class extended to using rugby manoeuvres, specifically the headlock: "I put the kids in headlocks. Boys-that's how it works, that's how I get the boys to do what I want-or I push them over while playing soccer or something."

Comments like this revealed a clear and strong power difference between Tim and his students. The headlock is a rugby tactic designed to disarm and immobilize the opposition. Tim's choice of it as a disciplinary method exemplifies not only his view of himself as the authority in the class but his perceived need to use strong masculinised behaviour to demonstrate and enforce his position (Skelton, 2001). While an onlooker could interpret Tim's interactions as bullying and stand-over tactics, and of using his greater strength and size to enforce compliant behaviour, Tim saw it as a positive use of our national sport to motivate and build rapport, especially with his male students.

Tim's descriptions of his teaching practice showed that with girls he tended to use a toned-down version of the strategies he used with boys. His view of the effectiveness of this approach was evident when he spoke of Victoria, a student he said who had created problems for her female teacher. However, he said, "Victoria hasn't been a problem for me. I give her plenty of jobs, give her some responsibilities, got her into cricket, and she's not a problem you know." Whether Tim perceived masculinised strategies to be equally appropriate for all "problem students" and whether he was aware that his gendered practices could have harmful implications for students (Lingard \& Douglas, 1999; Skelton et al., 2007) is unclear.

In line with his belief in recuperative masculinities discourses (Martino et al., 2004), Tim also saw himself as a father figure to boys. I asked him if he saw presenting himself as a father figure an important part of his role relative to his female students. He answered by saying, "There are plenty of role models for girls in this school, and you can't be a father figure to everybody." It is debatable whether Tim's apparent lack of awareness of issues around gendered behaviours was based on a lack of knowledge or whether a basic knowledge was superseded by the strength of his convictions around recuperative masculinities. Furthermore, his views about physical contact with students and his ensuing actions strongly aligned with his view of himself as a sportsman and the value of sport in building and maintaining relationships (Skelton, 2001). He also saw himself as "one of the most demonstrative teachers on the school staff ... [because] I'm always headlocking the kids." When I asked Tim if he associated headlocking with being demonstrative, he explained: "Well it is because, like, some boys are really stroppy and aggressive, and that's the way of building rapport, that bridge between you and them. If you don't have that, you can't get them to do anything, you know."

Although Tim's class was a mixture of 9- to 11-year-old boys and girls, Tim seemed to be caught up in meeting the needs of boys to the extent that the girls appeared overlooked or even forgotten. His interactions with boys were driven mainly by essentialist discourses, and his behaviours clearly aligned with dominant and desirable aspects of hegemonic masculinity (Epstein et al., 1998; Salisbury \& Jackson, 1996; Skelton, 2001), attributes that Ferguson 
(2004) claims are exalted by rugby-loving New Zealanders. Despite Tim’s apparent belief that the strongly physical rugby manoeuvres he used on boys were a positive way of building relationships, I would suggest they were also designed to demonstrate his power and ensure compliance. I also suggest that Tim's behaviours were based in the narrow version of masculinity that Martino (2008) sees as negating the value of expressivity and nurturing capacities. The extent to which they might also have met a need to publicly proclaim his heterosexuality, and to distance himself from any suggestion of homosexuality associated with his choice of career, is a point worth considering (Martino \& Berrill, 2003; Roulston \& Mills, 2000). Tim did concede that, on occasion, and in a public forum, if a student was upset, he might "sort of pat them on the shoulder and go 'Cool?'” However, his qualification that such a positive affirmation needed to take place in a public forum is telling. Either he wanted to be seen engaging in more nurturing behaviours or he saw himself more at risk of potential allegations of abuse or suspicion of homosexuality when he exhibited caring rather than rugby-based behaviours.

When I asked Tim if the age of his students influenced his attitudes towards physical contact, his reply that younger children actively seek physical contact with their teacher accorded with Jones's (2003) finding that young students seek more physical contact. For Tim “... little kids are different. Little kids do give you big cuddles. Little Jack comes up and gives me a big cuddle round the legs. It's like any other rug rat that gives you a cuddle. It's like 'Oh come on Jack, sort it out,' and he does.” However Tim's advice to Jack to "sort it out” informs the younger student that seeking the physical comfort of a teacher is neither appropriate nor desirable. The fact that Jack does "sort it out" demonstrates that the student has learned a lesson, one that in Tim's eyes is important and essential. Again, it seems that Tim saw his response as positive and helpful to the students in terms of learning what is appropriate, particularly for boys, in relationships.

Unlike Ronnie, Tim did not appear to experience any contradiction between what he thought children wanted and needed and his need for self-protection (Jones, 2003). While Tim remembered during his pre-service education being advised not to engage in physical contact with students, his strong convictions around recuperative masculinities (Martino et al., 2004) appear to have over-ridden his sense of vulnerability to accusations of abuse. His reference, at one point during the interview, to not touching a child, even on the shoulder, unless in a public forum, implies that he saw his use of headlocks as immune to misinterpretation or parental objection. The extent to which Tim's attraction to these discourses was influenced by a concern regarding his own image and identity as a result of working in a predominantly female environment is debatable but deserves consideration.

\section{Implications and Conclusion}

Although the three men interviewed in this study shared a common belief in the power of and need for physical contact between students and teachers, they demonstrated diverse ways of rationalising and managing it. While Ronnie and Tim had encountered warnings regarding the "dangers" of physical contact and were expected to adhere to strict guidelines, each responded in markedly different ways. In England, Ronnie's interactions with his students 
altered considerably following an in-service course, and while he saw the absurdity in the changes, he employed behaviours more closely aligned with hegemonic masculinities. New Zealand teachers are expected to adhere to national guidelines in their interactions with students, but Tim's classroom practices and management, and his attempts to build rapport with students, particularly boys, were influenced more by a strong belief in discourses around recuperative masculinities. Of interest, but not explored at the time, was whether Tim viewed his employment of physical contact practices closely associated with rugby, in a rugby-loving nation, as protection against potential allegations of abuse. His claim that he was one of the most demonstrative teachers in the school suggests he viewed his use of headlocking as an acceptable alternative to other potentially questionable forms of physical contact. In Sweden, Ivan had no recollection of warnings related to physical contact, and his interactions were not bound by formal policies or guidelines but rather by what he claimed to feel comfortable with as a human. In contrast to the suggestion that Tim's actions were strongly influenced by recuperative masculinities discourses, it is apparent that Ivan's behaviours were more aligned with equity discourses and the need to bring to teaching the individual characteristics and dispositions demonstrated in all aspects of one's life.

The information obtained from the interviews also demonstrate the effects that cultural mores and beliefs have on the way in which men teachers relate to their students. As Skelton et al. (2007) argue, gender differences are deeply embedded in societal expectations, underpinning ideas about what it is to be a socially accepted person. They claim that when men teachers feel pressured by societal expectations, a fear of being seen as homosexual, and governmental policies to act in ways deemed "properly masculine" (Skelton, 2000), they can end up, whether they are aware of doing so or not, working in ways contrary to those now seen to support academic achievement and challenge gender stereotypes (Martino, 2008; Martino et al., 2004; Skelton et al., 2007).

To pick up on the point made by Skelton et al. (2007), teachers are not always conscious of their gender-differentiated classroom practices. Martino's (2008) appeal to men to challenge stereotypes in the classroom cannot happen unless teachers first develop a sound research-based understanding of theories about gender, masculinity and schooling. Teachers need an understanding of the multiple ways masculinities and femininities are constructed and performed and how this process affects their lives and those of their students.

Despite the methodological and sampling limits of the study presented in this paper, the information it provides on men teachers' relationships with their students supports calls from a growing body of research to address issues of sexuality and gender not only in school-based in-service courses for teachers but as an integral part of all coursework during teacher education. Without a continued and rigorous approach to all aspects of pedagogy and relationships, it is unlikely teachers will develop the confidence and competence to interrogate gender regimes. The Swedish system of allowing student teachers to partially fulfil teacher education requirements in other countries could, in reverse, open up possibilities for students to immerse themselves in a culture that is working to embrace gender equality at all levels. It would be fascinating to predict the potential effects on the practices and beliefs of Ronnie and Tim, had they been given this opportunity. 


\section{References}

Arreman, I., \& Weiner, G. (2007). Gender, research and change in teacher education: A Swedish dimension. Gender and Education, 19(3), 317-337.

Berge, B. (2004). Whatever happened to the male teacher? Gendered discourses and progressive education in Sweden 1945-2000. History of Education Review, 33(2), 15-29.

Biddulph, S. (1997). Raising boys. Sydney: Finch Publishing.

Burman, E., \& Parker, I. (1992). Discourse analytical research. London: Routledge.

Carrington, B. (2002). A quintessentially feminine domain? Student teachers' constructions of primary teaching as a career. Educational Studies, 28(3), 287-303.

Cushman, P. (2005a). Let's hear it from the males: Issues facing male primary school teachers. Teaching and Teacher Education, 21(3), 227-240.

Cushman, P. (2005b). Will a revised code of practice change the practices of male teachers in their interactions with children? The New Zealand Journal of Teachers' Work, 2(2), 83-93.

Cushman, P. (2007). The male teacher shortage: A synthesis of research and worldwide strategies for addressing the shortage. KEDI Journal of Educational Policy, 4(1), 79-98.

Epstein, D., Elwood, J., Hey, V., \& Maw, J. (Eds.). (1998). Failing boys? Issues in gender and achievement. Buckingham: Open University Press.

Farquhar, S. (2001). Moral panic in New Zealand: Teachers touching children. In A. Jones (Ed.), Touchy subject: Teachers touching children. Wellington: Astra.

Ferguson, G. (2004). You'll be a man if you play rugby. Palmerston North: Dunmore Press.

Foster, T., \& Newman, E. (2005). Just a knock back? Identity bruising on the route to becoming a male primary school teacher. Teachers and Teaching: Theory and Practice, 11(4), 341-358.

Francis, B., \& Skelton, C. (2001). Men teachers and the construction of heterosexual masculinity in the classroom. Sex Education, 1(1), 9-21.

Francis, B., \& Skelton, C. (2005). Reassessing gender and achievement. London: Routledge.

Hood, L. (2001). A city possessed. Dunedin: Longacre Press.

Human Rights Commission. (1993). The Human Rights Act New Zealand. Wellington: Author.

Jacobsen, J., Kjeldsen, L., \& Poulsen, M. (2006). Trends in teacher education: Report from an ETUCE survey carried out in 2006. Copenhagen: University College of Greater Copenhagen.

Jones, A. (2003). Primary teacher trainees: Identity formation in an age of anxiety. AsiaPacific Journal of Teacher Education, 31(3), 181-193. 
Lingard, B., \& Douglas, P. (1999). Men engaging feminisms. Buckingham: open University Press.

Martino, W. (2008). Issues in boys' education: Encouraging broader definitions of masculinity in schools. Curriculum Leadership, 6(3) (electronic journal). Retrieved 13 October, 2008, [Online] Available: www.curriculum.edu.au/leader/issues_in_boys.

Martino, W., \& Berrill, D. (2003). Boys, schooling and masculinities: Interrogating the "Right” way to educate boys. Educational Review, 55(2), 99-117.

Martino, W., Lingard, B., \& Mills, M. (2004). Issues in boys' education: A question of teachers' threshold knowledges? Gender and Education, 16(4), 235-254.

New Zealand Education Institute Te Riu Roa. (1998). Physical conduct code of practice. Wellington: Author.

Renold, E. (2004). “Other” boys: Negotiating non-hegemonic masculinities in the primary school. Gender and Education, 16(2), 247-266.

Roulston, K., \& Mills, M. (2000). Male teachers in feminised teaching areas: Marching to the beat of the men's movement drums? Oxford Review of Education, 26(2), 221-237.

Salisbury, J., \& Jackson, D. (1996). Challenging macho values. London: Falmer.

Skelton, C. (2000). “A passion for football”: Dominant masculinities and primary schooling. Sport, Education and Society, 5(1), 5-18.

Skelton, C. (2001). Schooling the boys. Buckingham: Open University Press.

Skelton, C., Francis, B., \& Valkanova, Y. (2007). Breaking down the stereotypes: Gender and achievement in schools. Manchester: Equal Opportunities Commission. Retrieved 13 October, 2008, [Online] Available: www.eoc.org.uk/research.

Taguchi, H. (2005). Getting personal: How early childhood teacher education troubles students' and teachers' identities regarding subjectivity and feminism. Contemporary Issues in Early Childhood, 6(3), 244-255.

Thornton, M., \& Bricheno, P. (2006). Missing men in education. Stoke-on-Trent: Trentham Books.

UNESCO Institute for Statistics. (2008). Education statistics. Retrieved 13 October, 2008, [Online] Available: http://stats.uis.unesco.org.

Younger, M. (2007). The gender agenda in secondary ITET in England: Forgotten, misconceived, or what? Gender and Education, 19(3), 387-414. 